\title{
TOTAL PHENOL CONCENTRATIONS IN COFFEE TREE LEAVES DURING FRUIT DEVELOPMENT
}

\author{
Paula Rodrigues Salgado; ;osé Laércio Favarin²*; Roseli Aparecida Leandro³; Oscar Fontão \\ de Lima Filho ${ }^{4}$ \\ ${ }^{1}$ USP/ESALQ - Programa de Pós-Graduação em Fitotecnia. \\ ${ }^{2}$ USP/ESALQ - Depto. de Produção Vegetal, C.P. 09 - 13418-900 - Piracicaba, SP - Brasil. \\ ${ }^{3}$ USP/ESALQ - Depto. de Ciências Exatas, C.P. 09 - 13418-900 - Piracicaba, SP - Brasil. \\ ${ }^{4}$ Embrapa Agropecuária Oeste, C.P. 661 - 79804-970 - Dourados, MS - Brasil. \\ *Corresponding author <jlfavari@esalq.usp.br>
}

\begin{abstract}
Vegetables have a natural defense against external factors synthesizing phenolic compounds, which depends on the maturity stage and on the climate. Total phenol grades were extracted from mature and young coffee leaves and were analyzed in relation to yield, phenology and climate. The climatic conditions were described by air temperature, global radiation and daily insolation. Evaluations were made on height, diameter and length of reproductive branches to determine the respective vegetative growth rates of the plants. The amounts of total phenols in the plants at the production stage was $174.0 \mathrm{mg} \mathrm{g}^{-1}$ and $138.9 \mathrm{mg} \mathrm{g}^{-1}$ for young and mature leaves, respectively, and for plants without fruit formation $186.5 \mathrm{mg} \mathrm{g}^{-1}$ and $127.6 \mathrm{mg} \mathrm{g}^{-1}$ for young and mature leaves, respectively. The total phenol concentrations in young leaves with and without fruit formation were $25 \%$ and $46 \%$ greater compared to mature leaves. The secondary phenol synthesis in seed $\left(146.8 \mathrm{mg} \mathrm{g}^{-1}\right)$ was $31 \%$ lower than during grain maturation (212.4 $\mathrm{mg} \mathrm{g}^{-1}$ ). The total phenol metabolization depends indirectly on the temperature and on the global radiation, presenting an inverse trend in relation to these climatic variables. Crop protection management should take into consideration periods of endanger of this natural defense of the plant.
\end{abstract}

Key words: Coffea arabica L., mature leaves, young leaves, natural defense, climate

\section{CONCENTRAÇÕES DE FENÓIS TOTAIS NAS FOLHAS DO CAFEEIRO DURANTE DESENVOLVIMENTO DOS FRUTOS}

\begin{abstract}
RESUMO: Os vegetais apresentam defesa natural contra fatores externos, por meio da síntese de fenóis, as quais variam com as fases fenológicas e com o clima. Os teores de fenóis totais foram extraídos das folhas fonte e dreno e analisados em relação à produção de café, fenologia e clima. As variáveis climáticas consideradas foram: temperatura, radiação e insolação. Realizaram-se avaliações de altura, diâmetro e comprimento de ramos para determinar as taxas de crescimento. As quantidades de fenóis determinadas nas plantas com produção $\left(174,0 \mathrm{mg} \mathrm{g}^{-1}\right.$ e $138,9 \mathrm{mg} \mathrm{g}^{-1}$ - nova e madura) e sem produção (186,5 $\mathrm{mg} \mathrm{g}^{-1}$ e $127,6 \mathrm{mg} \mathrm{g}^{-1}$ - nova e madura) não variaram. No entanto, a concentração de fenóis nas folhas nova das plantas com e sem produção foi maior que a quantidade determinada nas folhas madura, da ordem de $25 \%$ e $46 \%$, respectivamente. A síntese de fenóis na granação $\left(146,8 \mathrm{mg} \mathrm{g}^{-1}\right)$ foi $31 \%$ inferior em relação às quantidades determinadas na maturação $\left(212,4 \mathrm{mg} \mathrm{g}^{-1}\right)$. A metabolização de fenóis depende, indiretamente, da temperatura e da radiação global. A orientação do manejo deve levar em consideração as épocas de comprometimento da defesa natural, em relação à produção de fenóis.

Palavras-chave: Coffea arabica L., folhas maduras, folhas novas, defesa natural, clima
\end{abstract}

\section{INTRODUCTION}

During coffee tree development the vegetative and reproductive phases occur at the same time and there is competition between both for photoassimilates. This is the main reason for the coffee production alternation, due to fruit development only on branches grown in previous years.
The principles for an ecological management are: $\left(1^{\text {st }}\right)$ every organism has natural enemies, $\left(2^{\text {nd }}\right)$ every plant tolerates a certain level of infestation or infection, $\left(3^{\text {rd }}\right)$ control management has to be selective and $\left(4^{\text {th }}\right)$ every crop can reach an equilibrium condition (National Research Council, 1996). Based on the second principle it can be concluded that for plants such as coffee trees that show defense mechanisms, 
growers should interfere in the natural crop defense system only when faced with the possibility of economic losses.

Generally, plants show defense mechanisms that react differently to biotic and abiotic stress agents. The nature and intensity of the reaction vary according to the age, adaptation level and the seasonal activity of the plant (Oliveira, 2003). Plant defense should be understood as a group of interconnected processes. The plant resistance and/or susceptibility can hardly be explained by a single mechanism (Oliveira \& Romeiro, 1991).

The biochemical compounds involved in the defense mechanisms are produced by a secondary plant metabolism, which does not affect directly plant growth and development, but has an essential role in plant metabolism (Strack, 1997). Carbohydrates are normally used during grain formation and vegetative growth of plants. They however may be diverted from their main metabolic path to the plant defense mechanism producing phenolic compounds. Highly productive years may represent high demands for carbohydrates, which would endanger not only the vegetative growth, but also the synthesis of phenolic compounds due to the lack of photoassimilates in the secondary metabolism.

Coffee bean and coffee leaves show a great amount of chlorogenic acids (CGA). Classically, CGA belong to a family of esters formed among certain trans-cinnamic acids and (-)-quinic acid (Clifford, 1999; Clifford, 2000). Due to antioxidant and antibiotic properties the CGA are involved in biologic functions in plants, such as the resistance to plagues and diseases (Matsuda et al., 2003).

Most research on this area, including research on coffee trees, uses plant parts under laboratory conditions. Therefore, the merit of the present study is that the experiment was carried out under field conditions with fruit-producing plants. The purpose was to evaluate the amount of total phenols in coffee leaves of growing plants during the fruiting stage as a function of the climatic conditions.

\section{MATERIALAND METHODS}

The experiment was carried out using fouryear-old coffee trees, Coffea arabica L cv. Obatã IAC 1669-20, grown in Piracicaba, State of São Paulo, Brazil, (22 $42^{\prime} \mathrm{S}$ and $47^{\circ} 38^{\prime} \mathrm{W}$, altitude $540 \mathrm{~m}$ ). The amount of total phenols was determined in young leaves (first pair of leaves) and mature leaves (third pair of leaves) taken from the medium portion of plagiotropic branches facing the rows and inter-rows, using 30 plants selected at random. Young leaves are light green, smooth, young, and recently expanded, compared to mature leaves which present a rough texture and intense green color.

Sample collections were made on 15 plants with pendent fruits and 15 plants without fruits, which flowers and fruits at the beginning of development stage were artificially avoided through manual collect. The leaves were collected from plants at the following fruiting stages: (i) fruits at the beginning of growth - E1 (22nd November, 2003), (ii) grain expansion E2 (12th December, 2003), (iii) seed - E3 (5th March, 2004), (iv) onset of grain maturation - E4 (19th May, 2004) and (v) the end of the grain maturation - E5 (12th July, 2004).

To determine the amount of total phenols, 50 $\mu \mathrm{L}$ of ground leaf extract in liquid nitrogen was placed in test tubes containing $450 \mu \mathrm{L}$ of distilled water, 250 $\mu \mathrm{L}$ of diluted (1:1) Folin Ciocalteu (1 N) reagent and $1.25 \mathrm{~mL}$ of sodium carbonate (20\%). The test tubes were stirred and readings were taken after 40 minutes using an absorbance spectrophotometer at $725 \mathrm{~nm}$. The tannic acid was used as a pattern to obtain the total amount of phenols (g equivalent tannic acid) (Dawra et al., 1988; Inoue \& Hagerman, 1988).

Plants sampled for the amount of total phenols were also analyzed in relation to the vegetative growth in order to estimate indirectly the influence of carbohydrate drains for phenol synthesis. Leaves were classified as in vegetative and reproductive growth (with fruits) or exclusively vegetative growth (without fruits).

The analyzed variables for producing plagiotropic branches were: growth rate in diameter, plant height growth rate and growth rate in length. The influence of the climatic conditions on the phenolic synthesis was evaluated using correlation indexes between the amount of total phenols and global radiation, maximum, average and minimum daily temperatures.

The experimental layout for data analysis was fully randomized utilizing four treatments (mature leaf of fruit-producing plant; young leaf of fruit-producing plant; mature leaf of non-producing plant and young leaf of non-producing plants) with fifteen replications. After analysis of variance the means were compared with the Student test (t-test), at 5\% probability. Average values of total phenols in young and mature leaves during the fruiting stages were also compared in paires by the t-test (E1 - E2; E2 - E3; E3 E4; E4 - E5) $(p<0.05)$.

\section{RESULTS AND DISCUSSION}

\section{Phenol production by coffee trees}

During the experiment, the coffee trees were not subject to water or nutritional stresses, were protected from plagues and diseases, and kept free from 
weed competition, once the synthesis of phenolic compounds by Coffea Arabica is affected by these conditions (Ramiro et al., 2006). Leaves infested with Hemileia vastatrix presented a trend towards a decrease in phenolic compounds, although not significant. Under such conditions, plant defense metabolism depended entirely on the carbohydrate demand by fruits, the vegetative growth and the weather conditions.

In relation to the synthesis of secondary metabolites there was no difference between fruit-producing and non-producing plants, for average values of total phenols $(p>0.05)$, not only for young leaves, but also for mature leaves (Table 1). This indicates that the secondary metabolites does not depend, exclusively, on the carbohydrates not allocated to fruits. The present experiment corroborates to this fact, since a great consumption of photoassimilates was verified in non-producing plants due to the vegetative growth of the plants at the developing stage (four years old).

The distribution and location of phenols in plants are not clearly known. However, the amount of phenols varies with plant organ, age, phenologic stage and weather conditions. In this study, the amount of total phenols in young leaves of fruit-producing plants (174.0 $\mathrm{mg} \mathrm{g}^{-1}$ ) and non-producing plants (186.5 $\mathrm{mg} \mathrm{g}^{-1}$ ) was greater than the amount found in the mature leaves (138.9 $\mathrm{mg} \mathrm{g}^{-1}$ and $127.6 \mathrm{mg} \mathrm{g}^{-1}$ ) $(p<0.05), 25 \%$ and $46 \%$, respectively (Table 1 ). These results are in agreement with the observations made by Oliveira \& Romeiro (1991), who also found a greater concentration of phenols in young leaves.

Young leaves are the second drains in importance, following fruits, and, therefore, nutrients and carbohydrates are allocated to them for their development. A similar pattern can be observed for secondary metabolites, which are also used to protect these immature organs. Such behavior may be explained by the morphology of young leaves, which are more susceptible to external factors due to their low lignification, which increases with tissue age. During the period prior to foliar maturation, leaves show a greater vulnerability to biotic and abiotic factors, which may require the translocation of photoassimilates to the secondary metabolism of young leaves. This localization has already been observed for leaves of Coffea canephora, that when young had clearly a higher concentration of chlorogenic acids (CGA) in relation to mature leaves, representing $46.9 \%$ and $25.8 \%$ of the total CGA, respectively (Mondolot et al., 2006).

In the E1 phenological phase (beginning of fruit growth) coffee leaves synthesized a greater amount of phenolic (147.2 $\mathrm{mg} \mathrm{g}^{-1}$ and $204.9 \mathrm{mg} \mathrm{g}^{-1}$ for mature and young leaves, respectively), nearly $25 \%$ greater in relation to the amounts found for the E2 phase (grain expansion) (117.9 $\mathrm{mg} \mathrm{g}^{-1}$ and 163.5 $\mathrm{mg} \mathrm{g}^{-1}$ for mature and young leaves, respectively) $(p<0.05)$. During the E3 phase (grain formation) the total phenol production decreased by 21\% (106.3 $\mathrm{mg} \mathrm{g}^{-1}$ and $146.8 \mathrm{mg} \mathrm{g}^{-1}$ for mature and young leaves, respectively), while in the $\mathrm{E} 4$ phase (onset of grain maturation) the production decreased again by $27 \%$ (134.0 $\mathrm{mg} \mathrm{g}^{-1}$ and $200.8 \mathrm{mg} \mathrm{g}^{-1}$ for mature and young leaves, respectively) (Table 2). Levels of total phenolic compounds around of $150 \mathrm{mg} \mathrm{g}^{-1}$ were also found in the leaves of Coffea arabica by Melo et al. (2006).

Table 1 - Amount of total phenols in young and mature leaves of fruit-producing and non-producing plants.

\begin{tabular}{lccc}
\hline Leaf & Fruit-Producing Plants & Non-Producing Plants & $p^{*}$ \\
\hline & $174.0 \pm 9.82$ & $186.5 \pm 12.88$ & $\mathbf{0 . 1 0 4}$ \\
Young & $138.9 \pm 11.63$ & $127.6 \pm 7.02$ & $\mathbf{0 . 6 4 7}$ \\
$p^{*}$ & $\mathbf{1 . 9 2 4} \mathrm{e}^{-06}$ & $\mathbf{1 . 9 7 4} \mathbf{e}^{-12}$ & \\
\hline
\end{tabular}

${ }^{*} p<0.05$ : averages are different; $p>0.05$ : averages are equal. \pm Standard error

Table 2 - Average amounts of total phenols in mature and young leaves during the fruiting stages compared as paires (E1 E2; E2 - E3; E3 - E4; E4 - E5) in coffee trees.

\begin{tabular}{lcc}
\hline Fruiting stages 1 & Mature leaves & Young leaves \\
\hline E1 - E2 & $\mathbf{1 4 7 . 2}-\mathbf{1 1 7 . 9 *}$ & $\mathbf{2 0 4 . 9 - 1 6 3 . 5 *}$ \\
E2 - E3 & $117.9-106.3$ & $163.5-146.8$ \\
E3 - E4 & $\mathbf{1 0 6 . 3 - 1 3 4 . 0 *}$ & $\mathbf{1 4 6 . 8}-\mathbf{2 0 0 . 8} *$ \\
E4 - E5 & $134.0-121.5$ & $200.8-212.4$ \\
\hline
\end{tabular}

${ }^{1}$ E1 = beginning of fruit growth; E2 = grain expansion; E3 = grain formation; E4 = onset of grain maturation; E5 = grain maturation; *significant difference $(p<0.05)$. 
Plants in which fruits were artificially avoided presented the same amount of total phenols (Table 1) as fruit-producing plants, probably because plants were at a developing stage (four years old) of intense vegetative growth. Before begin of this study it was hoped that non-producing plants would have high amounts of total phenols, due to the transport of carbohydrates to the main drain (fruit). The carbohydrate demand for vegetative growth may explain the low synthesis of total phenols in non-producing plants, once the vegetative growth of non-producing plants was greater than that of fruit-producing plants $(p<0.05)$. Nonproducing plants had a greater growth rate in diameter $(p=0.0064)$, height $(p=0.0025)$ and plagiotropic branche length ( $p=0.0023$ ) than fruit-producing plants (Figure 1).

Non-producing plants presented the same behavior as fruit-producing plants regarding the synthesis of total phenols during the fruiting stages, once there were no differences between fruit-producing and non-producing plants for the concentrations of total phenols (Table 1).

The production of fruits require great amounts of photoassimilates during grain expansion (E2) and grain formation (E3) stages (Chaves \& Sarruge, 1984), when there is greater dry matter accumulation (Figure 2). The carbohydrate amounts available for the secondary metabolism drop during these stages, which probably increases the plant susceptibility to microorganism attacks. Therefore, coffee plants show lower amounts of total phenols during the fruit growing and fruit development stages, between December and March in the present study.

When there is no visible fruit growth, which corresponds to the beginning of fruit growth (E1), $21.2 \%$ of the total dry matter (nearly 900 g plant $^{-1}$ ) is accumulated in fruits (Chaves \& Sarruge, 1984) (Figure 2). At this stage, the average amount of total phenols (147.2 $\mathrm{mg} \mathrm{g}^{-1}$ and $204.9 \mathrm{mg} \mathrm{g}^{-1}$ for mature and young leaves, respectively) is greater than the amount observed at the grain expansion stage (E2) (117.9 $\mathrm{mg} \mathrm{g}^{-1}$ and $163.5 \mathrm{mg} \mathrm{g}^{-1}$ for mature and young leaves, respectively), when fruits grow quickly and the total phenol accumulation reaches $44.6 \%$ of the total dry matter, corresponding to $1.995 \mathrm{~g} \mathrm{plant}^{-1}$. The same is observed during the grain formation stage (E3), when there is an average dry matter accumulation of $27.2 \%$, compared to the $7 \%$ accumulation during the grain maturation stage (E5). Therefore, the average amount of total phenols (121.5 mg g-1 and $212.4 \mathrm{mg}$ $\mathrm{g}^{-1}$ for mature and young leaves, respectively) at the E5 stage is greater than during E3 (106.3 $\mathrm{mg} \mathrm{g}^{-1}$ and $146.8 \mathrm{mg} \mathrm{g}^{-1}$ for mature and young leaves, respectively). There is a direct relation between the synthe- sis of phenols and the fruiting stages, because of the competition for carbohydrates between the primary and the secondary metabolisms (Figure 3).

\section{Phenol amounts and climate}

An inverse relation between phenol concentrations and temperatures was observed evidencing a decrease in the synthesis of phenols with increases in temperature (Figure 4).
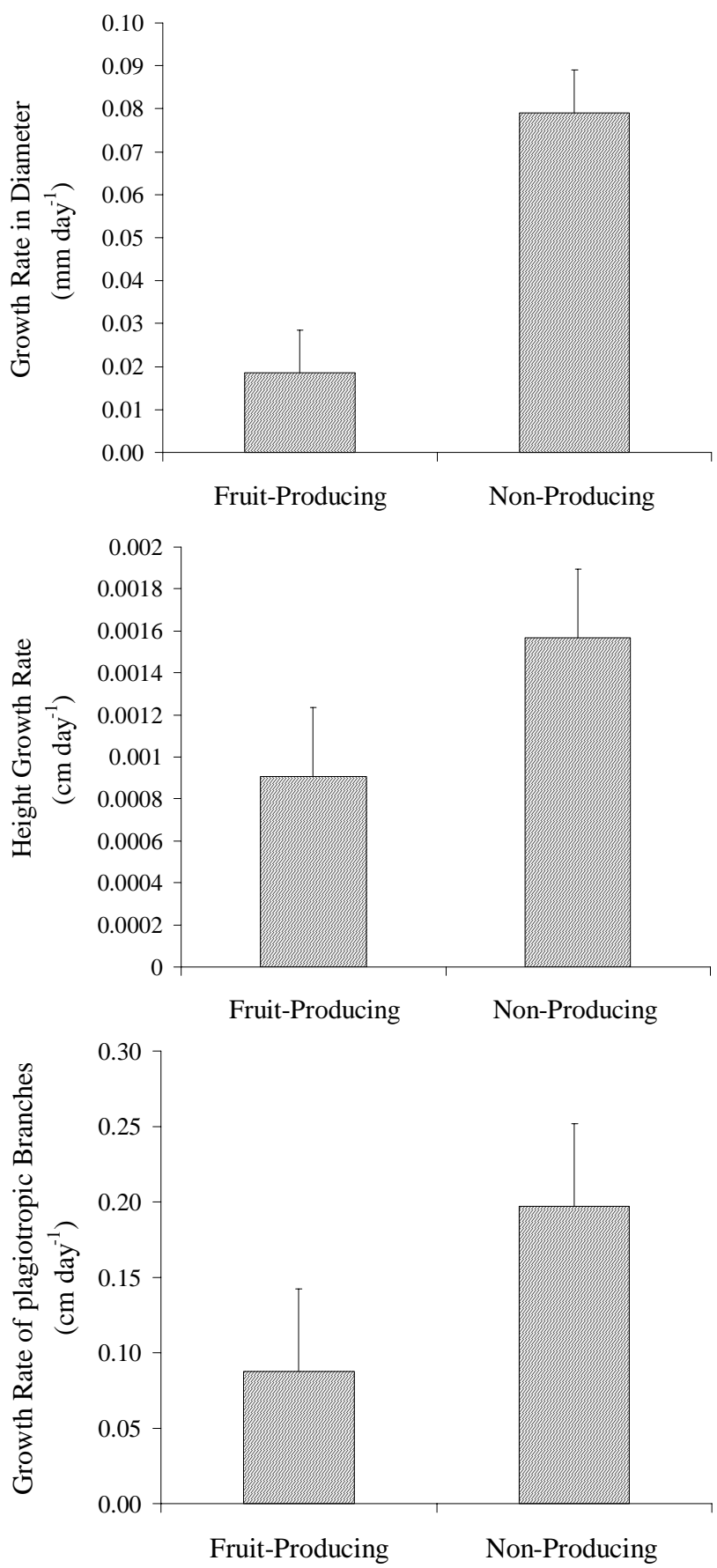

Figure 1 - Growth rate in diameter, plant height and palgiotropic branch length of fruit-producing and non-producing plants, from December 2003 to July 2004. Bars represent $\mathrm{SE}$. 


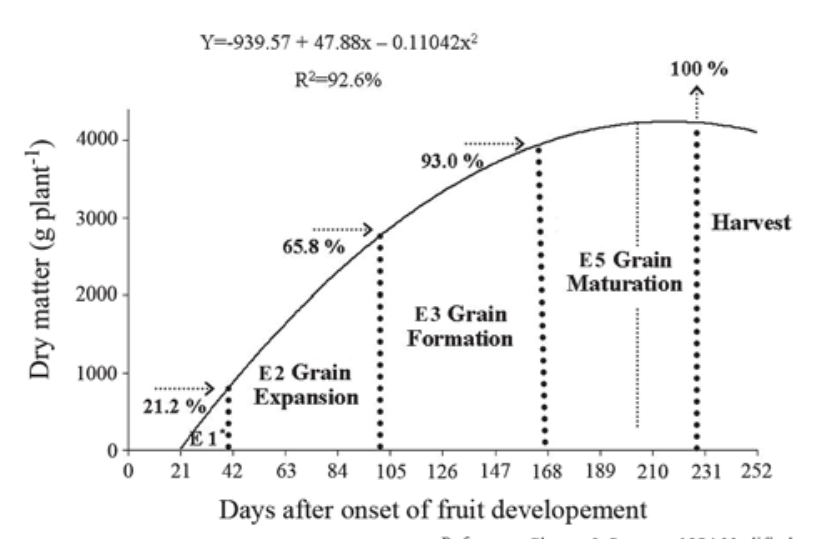

*E1: Begining of fruit growth

Figure 2 - Regression curve for dry matter accumulation (y: g plant $^{-1}$ ) by fruits of coffee trees as a function of their development (x: days).

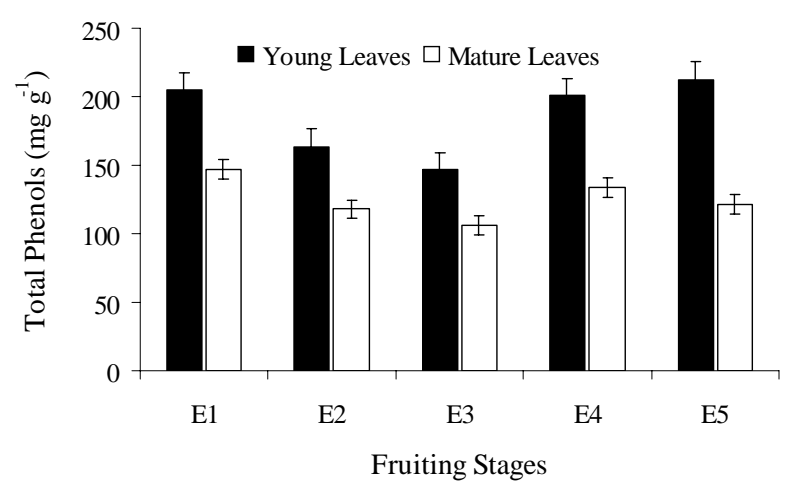

Figure 3 - Average amounts of total phenols in mature and young leaves during the fruiting stages $(\mathrm{E} 1=$ beginning of fruit growth; E2= grain expansion; E3= grain formation; E4= onset of grain maturation; E5= grain maturation) for coffee trees. Bars represent SE.

Fruit-producing plants demand greater amounts of carbohydrates for fruit growth during the fruit growing and fruit development stages, depending on the temperature, global radiation and precipitation. Therefore, the fruits and the vegetative growth of developing coffee trees, as it was the case of this experiment, act as alternate drains, reducing the carbohydrates available for the secondary metabolism and, consequently, the synthesis of phenols.

The synthesis of total phenols was influenced by the radiation in a similar way as temperature, according to an inverse relation (Figure 4). Such relation between climate variables indicates that temperature is a measurement related to heat, depending on the energy provided by global radiation.

\section{CONCLUSIONS}

The amounts of total phenols in developing coffee trees are same in leaves of fruit producing and
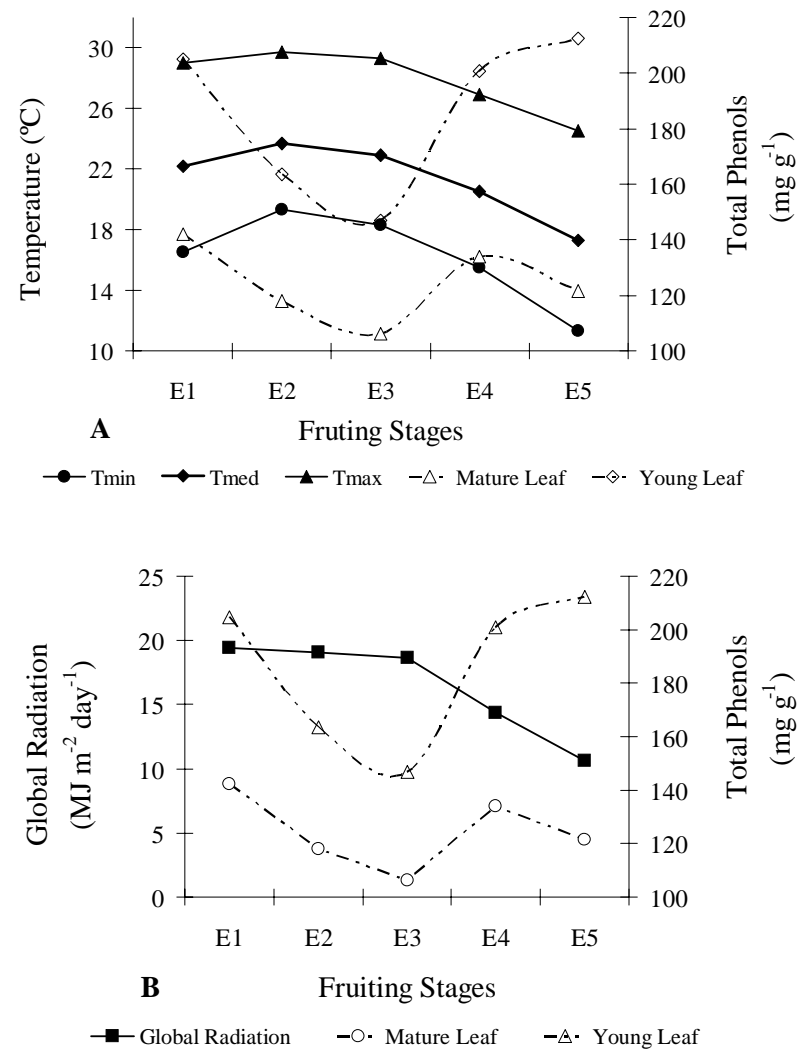

Figure 4 - Amounts of total phenols in mature and young leaves in coffee plants as a function of fruiting stages (E1 = beginning of fruit growth; E2 = grain expansion; E3 = grain formation; E4 = onset of grain maturation; E5 = grain maturation), temperature (minimum, average and maximum $\left({ }^{\circ} \mathrm{C}\right)(\mathrm{A})$ and global radiation $\left(\mathrm{MJ} \mathrm{m}^{-2} \mathrm{day}^{-1}\right)$ (B).

non-producing plants. The synthesis of total phenols decreases during the grain expansion and grain formation stages, from December through March (in Piracicaba, SP). Young leaves (drain) present a greater amount of total phenols than mature leaves, in fruit producing and non-producing plants. The synthesis of total phenols is inversely correlated with temperature and global radiation. The phytosanitary management of coffee plantations should take into account the periods when the plant natural defenses slow down by a drop in the synthesis of protective substances such as the phenols.

\section{REFERENCES}

CHAVES, J.C.D; SARRUGE, J.R. Alterações nas concentrações de macronutrientes nos frutos e folhas do cafeeiro durante o ciclo produtivo. Pesquisa Agropecuária Brasileira, v.19, p.427432, 1984.

CLIFFORD, M.N. Chlorogenic acids and other cinnamates: nature, occurrence and dietary burden. Journal of the Science of Food and Agriculture, v.79, p.362-372, 1999.

CLIFFORD, M.N. Chlorogenic acids and other cinnamates: nature, occurrence, dietary burden, absorption and metabolism. Journal of the Science of Food and Agriculture, v.80, p.1033-1042, 2000. 
DAWRA, R.K.; MAKKAR, H.P.S.; SINGH, B. Protein-binding capacity of microquantities of tannins. Analytical Biochemistry, v.170, p.50-53. 1988.

INOUE, K.H.; HAGERMAN, A.E. Determination of gallotannin with rhodanine. Analytical Biochemistry, v.169, p.363-369. 1988.

MATSUDA, F.; MORINO, K.; MIYASHITA, M.; MIYAGAWA, H. Metabolic flux analysis of the phenylpropanoid pathway in wound-hearling potato tuber tissue using stable isotope-labeled tracer and LC-MS spectroscopy. Plant Cell Physiology, v.44, p.510-517, 2003.

MELO, G.A.; SHIMIZU, M.M.; MAZZAFERA, P. Polyphenoloxidase activity in coffee leaves and its role in resistance against the coffee leaf miner and coffee leaf rust. Phytochemistry, v.67, p.277-285, 2006.

MONDOLOT, L.; FISCA, P.; BUATOIS, B.; TALANSIER, E.; KOCHKO, A.; CAMPA, C. Evolution in caffeoylquinic acid content and histolocalization during Coffea canephora leaf development. Annals of Botany, v.98, p.33-40, 2006.

NATIONAL RESEARCH COUNCIL. Ecologically based pest management: new solutions for a new century. Washington, DC: NRC, 1996. 144p.
OLIVEIRA, R.F. A planta sob estresse. In: CURSO DE ATUALIZAÇÃO EM CAFÉ 3., Campinas, 2003. Campinas: Consórcio Brasileiro de Pesquisa e Desenvolvimento do Café, 2003. p.44-50.

OLIVEIRA, J.R.; ROMEIRO, R.S. Compostos fenólicos, idade da folha e resistência do cafeeiro a Pseudomonas cicgorii e Pseudomonas syringae, pv. Garcae. Revista Ceres, v.38, p.445452, 1991.

RAMIRO, D.A.; GUERREIRO-FILHO, O.; MAZZAFERA, P. Phenol contents, oxidase activities, and the resistance of coffee to the leaf miner Leucoptera coffeella. Journal Chemical Ecology, v.32, p.1977-1988, 2006.

STRACK, D. Phenolic metabolism. In: DEY, P.M.; HARBONE, J.B. (Ed.) Plant biochemistry. London: Academic Press, 1997. p.387-416.

Received June 05, 2006

Accepted January 07, 2008 